\title{
Abílio Manoel e a ola latinoamericana no Brasil dos anos de 1970
}

\section{TÂNIA DA COSTA GARCIA*}

\begin{abstract}
RESUMO: A trajetória artística do cantor, compositor, produtor musical e radialista Abílio Manoel, falecido em 2010, confunde-se com o turbilhão de acontecimentos políticos que dominaram o Brasil entre o final dos anos de $1960 \mathrm{e}$ a obscura década de 1970, cujos ventos trouxeram para cá a Nova Canção latinoamericana. Iniciando sua carreira como compositor e cantor romântico, o caráter engajado de seu trabalho, foco desse artigo, manifesta-se em meados dos anos de 1970: data de 1972 o seu Lp América Morena; e, a partir de 1978 até 1982, produz e veicula o programa América do Sol na rádio Bandeirantes. O presente artigo, no rastro da carreira artística de Abílio Manoel, examina o lugar e os sentidos atribuídos à música popular latino-americana no Brasil, sobretudo a Nova Canção, durante a ditadura militar.
\end{abstract}

PALAVRAS-CHAVE: Nova Canção; Brasil; ditadura militar; Abílio Manoel

\section{Abílio Manoel and the ola latino-americana in 1970s Brazil}

\begin{abstract}
The artistic career of Abilio Manoel - a singer, composer, musical producer and broadcaster who died in 2010 - is confused with the maelstrom of political events that dominated Brazil between the end of the 1960 s and the obscure decade of 1970s, whose winds have brought here the Latin American New Song. He starts his career as a composer and romantic singer, the committed nature of his work, in which we focus, it manifests in the mid-1970s: his LP América Morena is from 1972; and from 1978 until 1982 he has produced and propagated the program América do Sol in Bandeirantes radio. The present article, in the trail of the artistic career of Abilio Manoel, examines the place and the meanings attributed to the Latin American popular music in Brazil, especially the New Song, during the military dictatorship.
\end{abstract}

KEYWORDS: New Song; Brazil; military dictatorship; Abílio Manoel.

\footnotetext{
* Tânia da Costa Garcia é Professora Adjunta do Departamento de História da Universidade Estadual Paulista (UNESP/Franca). Possui Livre Docência em História da América pela Universidade Estadual Paulista (2015). Cursou estágios de pós-doutorado no Department of Spanish, Portuguese e Latin American Studies at King's College London (2014), e na Universidade de São Paulo e no Instituto de Estudos Históricos Musicológicos da Pontifícia Universidad Católica de Chile (2007-2008). Possui doutorado em História Social pela Universidade de São Paulo (2001), mestrado em Ciências Sociais pela Universidade Federal de São Carlos (1995) e graduação em História pela Universidade Federal de Mato Grosso do Sul (1989). Tem experiência na área de História, com ênfase em História da América e do Brasil (estudos comparativos), atuando principalmente nos seguintes temas: música popular, arte engajada, identidade nacional e meios de comunicação. E-mail: garcosta@uol.com.br
} 
bílio Manoel - compositor, cantor, produtor musical e radialista - foi uma
daquelas figuras do meio artístico pouco conhecida do grande público,
circulando sempre num ambiente mais alternativo, aproximado da contra-cultura. Falecido em junho de 2010, aos 63, vítima de um infarto, Abílio pertence à geração de jovens brasileiros que viveu a ebulição cultural, o ideário libertário, a militância política e os revezes do golpe e da ditadura militar que marcaram os anos de 1960 e 1970, em diversos países da América Latina.

Em 1967, quando ingressou na Universidade de São Paulo, no curso de Física, embora o movimento estudantil estivesse na ilegalidade desde 1964 - ano do golpe militar e também do incêndio da sede da União Nacional dos Estudantes, no Rio de Janeiro - os estudantes, organizados na clandestinidade, ainda saiam às ruas em protestos. No campo das artes, o cinema, a música popular e o teatro, mesmo sofrendo os revezes da censura, não deixavam de fazer a denúncia dos males sociais e contestar a ditadura recém instaurada.

Esse foi um tempo em que arte e política se misturaram e atuaram conjuntamente em diferentes países do ocidente. Os avanços da esquerda com a Revolução Cubana em plena Guerra Fria polarizaram, como nunca, a vida política. No Brasil, particularmente na esfera da música popular, os famosos Festivais ${ }^{1}$ (19651969) - eventos promovidos pelas emissoras de televisão com apoio da indústria fonográfica - ao reunirem no palco e na platéia músicos e estudantes universitários, nesse momento politicamente conturbado, foram porta vozes da indignação social frente aos abusos do regime militar que, cada vez mais, comprometiam as liberdades democráticas.

Foi em meio a esse torvelinho de acontecimentos que Abílio Manoel participou de shows universitários promovidos pelos estudantes, no próprio campus e, em 1967, seguiu para representar a USP no Primer Festival Latinoamericano de la

\footnotetext{
1 A Era dos Festivais, como ficou conhecido o período entre 1965 e 1969 no Brasil, não constituiu um fenômeno isolado. Em países como o Chile (Festival de Mar de Viña del Mar, em 1959 e Festival da Nova Canção Chilena em 1969) e a Argentina (Festival de Cosquin, em 1961) e mesmo nos EUA (Woodstock em 1969) assistimos à fenômenos bastante semelhante. Também, de modo similar, tais eventos musicais, ao reunirem a juventude em torno da canção, contribuíram com a atmosfera de rebeldia e o arrebatamento político daqueles anos.
} 
Canción Universitária, realizado pelos estudantes da PUC do Chile, em Santiago ${ }^{2}$ um dos primeiros festivais realizado por estudantes chilenos, dentro dos muros da universidade e com a participação de estudantes-artistas de diferentes países latinoamericano. Abílio Manoel venceu o Festival na categoria "composição", com a canção Minha Rua, marcha-rancho sem nenhum parentesco com a sonoridade latinoamericana. Segundo relato do próprio músico ${ }^{3}$, foi nessa época, em Santiago, que, pela primeira vez, escutou os nomes de Violeta Parra e Victor Jara.

Em 1968, concorreu com outras canções no Festival da TV Excelsior e no FIC. Ano em que também foi decretado o AI5, pondo um fim às liberdades civis e suspendendo a garantia de habeas corpus. Com o recrudescimento da ditadura os festivais iam perdendo seu caráter contestador e, despolitizados, esmoreciam. Em 1969, a TV Tupi de São Paulo, ainda insistindo no formato, apresentou o II Festival Universitário4, cuja última edição seria em 1971. Abílio Manoel, outra vez, foi um dos vencedores com o samba rock Pena Verde.

Embora circulando num ambiente em que o engajamento político estava na ordem do dia, as canções de Abílio Manoel eram predominantemente românticas. A fase mais politizada de sua trajetória teria início em meados da década de 1970 período de distensão política da ditadura militar. De 1976 data seu Lp América Morena (Som Livre), recheado de referências à Nova Canção latino-america ${ }^{5}$; entre 1978 e 1982, pela Rádio Bandeirantes, produz o programa América do Sol, dedicado exclusivamente ao repertório popular latino-americano.

\footnotetext{
${ }^{2} \mathrm{O}$ evento gerou um Lp com as canções do Festival, lançado no ano seguinte.

${ }^{3}$ Entrevista, realizada por mim, com Abílio Manuel em 24/02/2008.

4 "O Festival Universitário da Canção Popular foi realizado pela TV Tupi em quatro edições (de 1968 a 1971), no Rio de Janeiro e em São Paulo, exclusivamente para compositores universitários." Dicionário Cravo Albin da Música popular Brasileira.

${ }^{5}$ Como Nova Canção latino-americana denomino aqui a Nueva Cancion Chilena e o Nuevo Cancionero Argentino. Ambos repertórios possuem grandes semelhanças não só em relação às temáticas sociais das canções, mas também à mediação com o folclore nacional e andino, e à evocação de uma unidade latino-americana.
} 


\section{A Nova Canção no Chile, na Argentina e no Uruguai}

O movimento da Nova Canção, ocorrido em países da América do Sul, como Chile, Argentina e Uruguai, embora guarde cores locais, guarda características em comum, desde o forte vínculo com a canção folclórica local, menos comercial; os cantautores Violeta Parra e Atahualpa Yupanqui ${ }^{6}$ como referência dos movimentos; o repertório engajado, identificado com as ideologias de esquerda7; até a reivindicação de uma unidade/identidade latino-americana ${ }^{8}$. Vale ainda lembrar que, nos três países, a Nova Canção antecede às ditaduras que, entre final da década de 1960 e início de 1970, se apossavam do poder, via golpes militares, colocando um ponto final na efervescência cultural e política que contagiava segmentos da juventude dessas sociedades.

Quanto às singularidades, são distintos, por exemplo, os eventos que marcaram o surgimento do movimento nos 3 países, acompanhados de seus artistas de maior projeção e circulação. Na Argentina, o Manifiesto del Nuevo Cancionero, da autoria do poeta e compositor Armando Tejada Goméz, publicado em 1963, num jornal de Mendoza, e assinado por artistas como Mercedes Sosa, Tito Francia, Oscar Matus, anuncia o projeto e os argumentos que o fundamentam. O primeiro disco engajado de Mercedes Sosa, Canciones con Fundamento (El Grillo, 1965), tem canções, na sua maioria, da autoria de Tejada e Matus. Mercedes, pela qualidade da sua interpretação e dos repertórios gravados, tornou-se a maior representante do Nuevocancionero, não só na Argentina, mas em toda a América Latina. Outros cantautores importantes que deram sequência ao movimento na Argentina, foram Cesar Isella e Victor Heredia.

\footnotetext{
${ }^{6}$ Os compositores e intérpretes Violeta Parra e Atahualpa Yupanqui foram os primeiros a conciliar tradição e modernidade ao valorizarem o cancioneiro folclórico, e tratarem essa tradição como algo vivo, em sintonia com as demandas de seu tempo

7 Trata-se de um período de forte tensões sociais que clama por mudanças políticas, dentro de um panorama internacional que tem a Guerra Fria e a Revolução Cubana como pano de fundo, polarizado entre ideologias de direita e de esquerda.

${ }^{8} \mathrm{~A}$ projeção de uma identidade/unidade latino-americana constitui um dos aspectos em comum entre os repertórios chileno, argentino e uruguaio. Precocemente, já em seu primeiro disco o uruguaio Daniel Viglietti grava, de sua autoria "Canción para mi América". Em 1967, o chileno Patrício Mans lança Sueño Americano. No final da década de 1960, o compositor e intérprete do Novo Cancioneiro Argentino, Cesar Isella, compõe com Tejada Goméz a famosa Canción con todos, espécie de hino da unidade latino-americano.
} 
No Chile, embora a Peña de los Parra, criada em 1965, tenha promovido a aproximação entre músicos do cancioneiro folclóricos envolvidos não só com a renovação estética da música popular chilena, mas também com as ideologias de esquerda, o termo "nova canção" só aparece com o Primer Festival de La Nueva Cancion Chilena, em 1969, cujo nome de batismo foi dado por Ricardo Garcia, figura ligada a cultura dos festivais e radialista. Isabel e Angel Parra, filhos de Violeta, fundadores da famosa Peña, deram prosseguimento ao trabalho da mãe juntamente com outros importantes cantautores da canção folclórica chilena, como Rolando Alarcon, Patrício Mans e Victor Jara. Jara também foi produtor musical do grupo Quilapayum que, ao lado de outro com formação bastante parecida, Inti-ilimani, jovens universitários engajados às ideologias de esquerda - tiveram lugar de destaque no movimento. Vale lembrar que no Chile, diferentemente dos outros dois países, a Nova Canção alcançou o poder, isto é, deixou de ser uma canção de protesto contra a ordem dominante, para fundar e ajudar a consolidar a experiência de um governo socialista democrático, sob a batuta de Salvador Allende, candidato à presidência pela Frente Popular, que venceu as eleições em 1970. Entretanto, com a ditadura instaurada em 1973, muito de seus músicos, assim como os argentinos e os uruguaios de meados da década de 1970 em diante, foram perseguidos, torturados e até mesmo assassinados, ou partiram para o exílio.

No Uruguai, é consenso que não houve propriamente um movimento, e sim uma geração de músicos que, por um lado, se alinhou ao movimento argentino e chileno e, por outro, se posicionou frente aos conflitos políticos que, naqueles anos, tomavam conta do país, gravando canções com temáticas de crítica social em meio ao cancioneiro folclórico. O marco inicial dessa produção está situado na década de 1960. Em 1962, pela Antar, o duo Los Olimareños, grava o álbum, que leva o mesmo nome, contemplando temáticas sociais em pelo menos 3 canções do disco. Em 1963, também pela Antar, Daniel Viglietti lança o seu primeiro disco com canções engajadas, Canciones Folkloricas y seis impresiones para canto y guitarra. Em 1966, Alfredo Zitarrosa entra em cena com Canta Zitarrosa, pela Tonal, contendo ritmos folclóricos com temáticas românticas e algumas canções de crítica social de outros autores. 
Portanto, quando Abílio Manoel esteve no Chile em 1967 o movimento que daria origem a Nueva Canción Chilena estava em processo de formação. De qualquer modo, já havia uma produção expressiva desse repertório no país com a qual provavelmente teve contato. Em 1965, por exemplo, já estava disponível no mercado o Lp La peña de los Parra, com canções da autoria de Angel Parra, Alarcon e Manns. De 1966, pela Demon, é o disco de Manns, Entre mar y Cordillera, também já

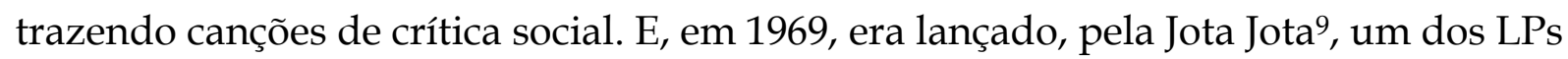
mais engajado de Victor Jara, Pongo en tu manos Abiertas.

No Brasil, teríamos que esperar até os anos de 1970 para entrar em contato mais efetivo com essa produção. Num breve levantamento do que foi lançado aqui, teve lugar de destaque a gravadora nacional Copacabana. Em 1974, trazia para o público brasileiro Chile Canta, el disco de plata del folclore chileno com Violeta Parra, Isabel Parra, Angel Parra e Victor Jara; os Lps de Violeta Parra, Canciones Inéditas Vol. 1 e 2, respectivamente em 1975 e 1976, também foram obras lançadas pela Copacabana; e ainda Santa Maria de Iquique, do conjunto chileno Quilapayum, em 1975; Viva Chile do grupo Inti-illimani, em 1977; e o LP do cantautor Patricio Manns, El Sueño Americano, lançado originalmente no Chile em 1967 e sem data registrada no Brasil. Ainda, antes da estreia do programa América do Sol, a Philips e a Phonogran, editavam no Brasil, dois álbuns de Mercedes Sosa: Mercedes Sosa, em 1976 e A Arte de Mercedes Sosa, em 1977.

Também foi na década de 1970 que figuras da MPB, como Milton Nascimento, Elis Regina e Chico Buarque ${ }^{10}$, se aproximaram da música popular latino-americana, incluindo canções desse repertório em seus discos. E, inspirados nessa nova onda latino-americana, surgiram os grupos Tarancón ${ }^{11}$ e Raíces de América, respectivamente em 1973 e 1980.

\footnotetext{
${ }^{9}$ Pertencente à Juventude Comunista, logo rebatizado como Discoteca del Canto Popular.

${ }^{10}$ Milton Nascimento, no álbum Clube da Esquina 1 (1972), lançado pela Odeon, gravou duas canções em espanhol "Dos Cruces" (Carmelo Larrea) e San Vicente (Milton e Fernando Brant); em Geraes (1976) também pela Odeon, incluiu no repertório Volver a los 17 de Violeta Parra cantado em dueto com a argentina Mercedes Sosa. Elis Regina tem no seu LP Falso Brilhante (1976), pela Philips, sua maior aproximação com o repertório do cancioneiro latino-americano e Chico Buarque encontra-se mais identificado com a Nova Trova Cubana - nesse momento em intensa troca com músicos da Nova Canção - gravando canções de Pablo Milanés e Silvio Rodrigues.

${ }^{11}$ Sobre o Grupo Tarancón ver GARCIA, Tânia. Taracón: a invenção sonora de um Brasil latino-americano. In revista ArtCultura, vol. 8, n.13, julho-dezembro de 2006.
} 


\section{Abílio Manoel e a ola latinoamericana}

Estimulado pelo contato com as sonoridades latinas que nos anos 70 alcançavam finalmente o Brasil, Abílio Manuel formaria, em 1975, o grupo Terra Livre. O resultado deste trabalho foi reunido no disco América Morena, lançado pela Som Livre, em 1976. As músicas da autoria de Abílio Manoel, cantadas em português, apresentam temáticas que, indiretamente, sugerem algum alinhamento político. $\mathrm{O}$ arranjo musical, embora conte com a presença de instrumentos andinos como a zampoña, a quena, o charango, mesclados aos timbres e acordes clássicos da música popular brasileira, remete o ouvinte a um universo familiar, próximo à MPB. Diferente, portanto, do disco do grupo Tarancón, Gracias a la vida, lançado no mesmo ano, cujo repertório era composto pela Nueva Cancion Chilena e por canções folclóricas de diferentes países do subcontinente. Resultado: enquanto América Morena foi um fracasso de venda, segundo depoimento do próprio Abílio, Gracias a la vida é, até hoje, o disco mais vendido do Tarancón. Vale observar que o público de Abílio Manuel, ou almejado por ele, era o mesmo do grupo Tarancón, qual seja, universitários e intelectuais simpatizantes das ideologias de esquerda e/ou da contracultura $^{12}$

O melhor da relação de Abílio com a música popular latino-americana estaria por vir. Um ano depois, em 1977, estreava na rádio Bandeirantes FM o programa América do Sol. A Bandeirantes FM, cujas transmissões tiveram início no ano de 1975, na cidade de São Paulo, caracterizava-se por sua programação alternativa, veiculando basicamente MPB, rock, soul e jazz.

América do Sol ia ao ar todos os domingos, das $19 \mathrm{~h}$ às $20 \mathrm{~h}$, com produção e locução de Abílio Manoel. Durante uma hora ouvia-se exclusivamente música latinoamericana dos anos 60 e 70, desde a nova-canção chilena e argentina, a nova trova cubana até o repertório folclórico dos diferentes países da região. A Bandeirantes FM

\footnotetext{
12 Sobre essa aproximação entre as ideologias de esquerda e a contra-cultura no Brasil dos anos de 1970 ver GARCIA, Tânia. Taracón: a invenção sonora de um Brasil latino-americano. In revista ArtCultura, vol. 8, n.13, julho-dezembro de 2006
} 
atingia, em 1979, um raio de 100 km, alcançando diversas cidades da grande São Paulo.

Abílio, idealizador e diretor artístico ${ }^{13}$ do programa, ao contrário dos disckjokeys que eram assediados pelas gravadoras interessadas em lançar seus discos, fazia o caminho inverso, percorrendo essas empresas em busca de repertório. Na época - e ainda hoje - as lojas do ramo no Brasil ofereciam pouca ou nenhuma opção no que se refere a música popular dos países vizinhos. Assim, muitas das canções ouvidas no programa de Abílio, eram provenientes de material importado. Certamente a barreira do idioma, além de outros fatores culturais e de mercado, não estimulavam as gravadoras em difundir o repertório no Brasil.

Nesses anos, meados da década de 1970, o movimento estudantil, aproveitando-se das brechas do conturbado processo de redemocratização, retomava as ruas reivindicando o aprofundamento da liberalização política.

Mesmo que a contragosto do grupo de militares conhecido como "linha dura", em dezembro de 1978 o AI-5 era revogado e na seqüência, em 1979, a UNE entrava novamente para a legalidade. Também em 1979, seguindo o planejamento de uma abertura gradual, era promulgada a lei de Anistia. Com a prescrição dos crimes e delitos cometidos entre 1964 e 1979 pelos agentes do poder e pelos "subversivos", muitos voltaram do exílio, retomando, aos poucos, seus vínculos com o país.

Foi em meio a esta atmosfera de distensão, iniciada com o governo do General Ernesto Geisel, em 1974, que o programa America do Sol fez coro com outras vozes, contribuindo com o processo de redemocratização, ora vivendo situações de constrangimentos - acusado de desrespeitar a censura previa o programa seria suspenso por um mês - ora de euforia, burlando a repressão e transformando a Nova Canção e as sonoridades do folclore latino-americano numa espécie de hino de resistência à ditadura.

A década de 1970, no Brasil, conheceu um diálogo diverso da década de 1960 entre arte e política. Se nos 60 essa relação fora intensa, a ponto de se acreditar

\footnotetext{
${ }^{13}$ Abílio Manuel - músico e compositor - não era um homem de rádio. Sua relação com o meio se restringiu ao programa América do Sol, que depois da rádio Bandeirantes foi levado para a Rádio USP em 1984.
} 
que a arte representava um caminho para a revolução, nos 70, embora esse viés militante tenha arrefecido graças ao forte esquema de repressão, permanecia seu potencial contestador, persistia o engajamento ${ }^{14}$.

\section{A programação de América do Sol}

Os roteiros ${ }^{15}$ analisados de América do Sol, produzidos exclusivamente por Abílio Manuel, sugerem que o foco principal do programa era a divulgação da cultura dos povos latino-americanos. A primeira vista, parecia ter um perfil educativo, conectando o ouvinte brasileiro à música dos países vizinhos. Esta, sem dúvida, era a intenção de seu diretor, a fim de desviar a atenção do censor do caráter supostamente "subversivo" do programa. Chama atenção nos roteiro que tivemos acesso o pouco espaço para o improviso - provavelmente, em função da censura. Todos os comentários sobre as canções veiculadas, mesmo os mais triviais eram previamente escritos.

Alguns domingos eram dedicados exclusivamente a um intérprete e/ou compositor da música folclórica latino-americana; noutros a temática eram os instrumentos típicos do folclore andino; às vezes, reuniam-se canções folclóricas de um determinado país, interpretadas por diferentes artistas. A locução programada também buscava ilustrar o ouvinte, veiculando informações breves sobre a história e a geografia do país visitado pelas canções. Traçava-se ainda um perfil dos artistas apresentados e comentários elucidativos sobre os instrumentos utilizados, pouco familiares à escuta brasileira. Intercalavam-se, por exemplo, programas mais engajados, só músicos da Nueva Cancion Chilena, com outros de temáticas predominantemente folclóricas, dedicados às canções rapanui da ilha de Páscoa.

De um modo geral o repertório era muito variado, incluindo desde a Nova Trova Cubana, representada por Silvio Rodrigues e Pablo Milanez; a Nova Canção

\footnotetext{
${ }^{14}$ A arte engajada, de acordo com Benoit Denis, em Literatura e engajamento, Bauru, SP. Edusp, 2002, diferentemente da arte militante - que pressupõe a subordinação dos ideais estéticos a uma determinada doutrina política ou filiação partidária - preserva seu compromisso com o social, sem sacrificar a liberdade criativa, sem submeter-se ao aprisionamento ideológico. Essa forma de arte é sempre interessada e tem um compromisso ético.

${ }^{15}$ Esta documentação foi doada por Abílio Manoel para essa pesquisadora.
} 
Chilena na voz da família Parra, Victor Jara, Quilapayum, Inti-illimani; as zambas de Mercedes Sosa, as milongas de Athaualpa Yupanqui, o cancioneiro uruguaio de Daniel Viglietti e Alfredo Zitarrosa; e ainda as mais diversas canções folclóricas de diferentes povos da América Latina. A música brasileira raramente era veiculada, mesmo assim, figuravam na programação canções de Chico Buarque, Milton Nascimento e, numa linha mais folclórica, uma banda de pífanos do nordeste do país.

Também para burlar a censura prévia, palavras como "canção de protesto", "revolução", "luta", "combate", "resistência", entre outras comuns ao jargão militante e muitas vezes presente na poética das canções, não constavam do vocabulário do precavido locutor. Entretanto, seu público alvo, ao sintonizar a Rádio Bandeirantes FM, às 19 horas do domingo, sabia exatamente o que buscava: um espaço para compartilhar e manifestar seu inconformismo com a situação política do país.

Cantar e escutar estes ritmos era uma forma de posicionar-se ideologicamente contra a ditadura. Se a canção de protesto brasileira tornara-se proibitiva, o repertório latino-americano, por ser oriundo de uma cultura "distante" e ainda cantado em outra língua, constituía uma alternativa para manifestar publicamente a indignação e o repúdio ao regime militar.

Para que o leitor possa ter uma idéia mais próxima do que foi América do Sol transcrevemos a seguir alguns excertos de roteiros da programação. Todos os domingos América do Sol iniciava com a seguinte chamada: "Viajando rios, montanhas, do altiplano andino aos pampas, cruzando fronteiras... que a nossa música seja a bandeira comum da América Latina."

Nesse rápido tur pela paisagem da região, evocava-se uma identidade latino-americana representada pelos diálogos musicais. Os ouvintes brasileiros, ao participar desta audição, aproximando-se durante uma hora dos povos vizinhos, integravam um coro imaginário contra as ditaduras do subcontinente.

No domingo de 16 de setembro de 1977, América do Sol apresentava a obra de Atahualpa Yupanqui, considerado o precursor da nova-canção pelos músicos do movimento, tanto no Chile como na Argentina. Após a execução de Duerme Negrito, 
Abílio Manuel, trabalhando taticamente para burlar a censura, tecia o seguinte comentário sobre a canção:

(...) dentro de seu estilo narrativo, Atahualpa vai arregimentando personagens humildes de seu povo, suas recordações, até chegar aos tempos de infância, quando, então, foi acalentado por uma canção de ninar de origem centro-americana... Duerme Negrito, adaptada por ele, foi aqui mostrada pelo grupo Quilapayun do Chile.

Embora tenha uma introdução cuja melodia lembre, de fato, uma canção de ninar, Duerme Negrito, tornou-se parte do repertório de denúncia social, integrado à nova canção latino-americana. Pertencente ao folclore da região caribenha, próxima a Venezuela e Colômbia, foi recopilada por Atahualpa, que a registrou por volta de 1969, em Paris. Posteriormente foi gravada por outros músicos como Victor Jara, Mercedes Sosa, e Daniel Viglietti. A versão veiculada por Abílio em América do Sol era interpretada pelo grupo chileno Quilapayun, forte representante da militância de esquerda e, nesse momento, já vivendo no exílio. Portanto, a ingênua canção de acalanto transgredia simbolicamente os limites de tolerância da ditadura.

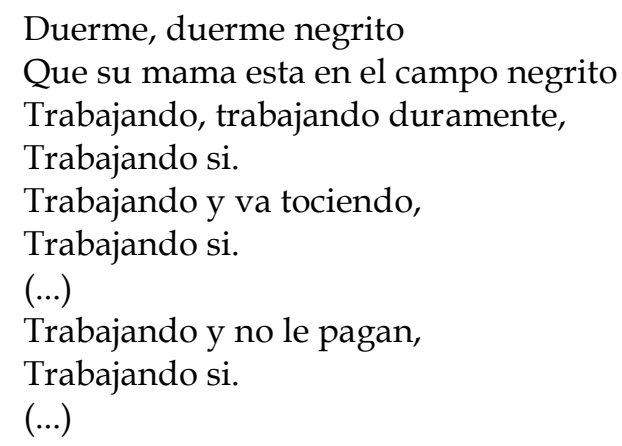

Em 19/06/1977 o programa trazia “(...) as principais regiões folclóricas do Chile e seus mais representativos estilos musicais, através de interpretações de Margot Loyola, Violeta Parra, Inti-illimani, Los Cuatro Cuartos e Victor Jara."

Chama atenção, aqui, a miscelânea - talvez proposital - de tendências diversas da música chilena: Margot Loyola, folclorista oficial da música nacional chilena; Los 4 Cuartos, grupo representante do neofolclore, que no final dos anos 60, havia se posicionado contra a candidatura de Allende; Victor Jara, integrante do movimento da NCChilena e do grupo de artistas alinhados com a Unidade Popular, durante a campanha de Allende para presidência, assassinado logo após o golpe 
militar, encabeçado por Augusto Pinochet. É cabível supor que tal seleção visava uma cronologia do cancioneiro popular chileno.

Especificamente ao grupo Inti-illimani foi dedicado uma série de três programas. Esse conjunto chileno, ao lado do Quilapayum, representa o auge da militância a que se prestou a NCCh. Formados por estudantes universitários, ambos participaram ativamente da campanha de Allende à presidência e depois atuaram em prol da consolidação do seu governo. Na época do golpe, por sorte do destino, os dois estavam em turnê fora do Chile. Em 15/05/77 Abílio apresentava o grupo:

O grupo Inti-illimani que acaba de encerrar a audição especial de hoje, enfocando a nova música chilena, acredita na preservação de seus autênticos valores culturais, como o folclore, e sempre soube colocar seus ideais através de uma cuidadosa escolha de seu repertório, mostrando ora os seus compositores mais importantes, ora criando, ora reconstituindo um tema latino-americano. Por isso a nossa homenagem aos defensores da cultura popular deste terceiro mundo... Encerramos nossa audição com Cancion del poder popular de Luis Advis (...), e depois La segunda independência de Ruben Lena, um canto livre desta América do Sol.

Destacando o valor do folclore e a preocupação do grupo em preservá-lo, Abílio levava ao ar duas músicas absolutamente distantes desta proposta. "Cancion del poder popular" foi gravada pela primeira vez no disco Canto al Programa, editado pela DICAP (Discoteca do canto popular - selo discográfico pertencente a Juventude Comunista do Chile), em 1970. Esse LP foi dedicado à campanha de Allende para a presidência da República. A melodia é introduzida por instrumentos andinos - quena e charango - típicos da NCCh, seguida imediatamente por um ritmo de marcha militar. A canção convoca o povo a participar da luta em defesa do governo de Allende. As vozes masculinas, em coro, conferem um caráter heróico à missão.

"La segunda independência", canção do disco Viva Chile de 1973, conclama ao som de quenas, violões, charangos e bombo, todos os países da América Latina para uma "segunda luta pela libertação", agora contra o imperialismo norte-americano - idéia propagada por intelectuais latino-americanos, desde fins do século XIX e início do século XX, e que volta com toda força nas décadas de 1960 e 1970, difundida pelas ideologias de esquerda que defendem a revolução socialista como única solução para a libertação da opressão capitalista. 
Em dezembro de 1978, ano em que termina a vigência do AI5 (13 de outubro de 1978), o roteiro do programa, particularmente as falas do locutor, assumem um tom notoriamente mais ousado se comparados às anteriores: anuncia a Nova Trova Cubana e seu compositor Silvio Rodrigues como a expressão de um homem novo que se constituiu na luta pela revolução. Não deixa ainda de fazer breve menção ao próprio Fidel Castro:

A Nova Trova Cubana representa o mais importante movimento musical daquele país, desde Carlos Puebla que marcou com seu canto todos os passos da autodeterminação de um povo oprimido, antes da chegada de Fidel Castro. Ouvimos nesta seqüência de América do Sol, Silvio Rodriguez interpretar, de sua autoria, El Rei de las Flores. (...). O trabalho deste compositor mostra a atmosfera de luta do homem novo, que abandonou valores individualistas e alienantes acompanhando a maturidade de todo um processo social.

Desfrutando do processo de redemocratização em curso, em 10/06/79 o programa apresenta os discos Canto Libre (1970) e Canciones Chuecas (1971) do uruguaio Daniel Viglietti. Vale lembrar que o álbum Canto libre traz duas canções de Jorge Salermo militante do movimento MLN-Tupamaros, assassinado em 196916, período de radicalização política no Uruguai, tanto dos grupos de esquerda que aderem a luta armada, como da direita que, no poder, intensifica o seu aparato repressivo. Canciones Chuecas, na mesma toada do Lp anterior, traz canções militantes de autoria própria e de compositores chilenos, como Violeta Parra, e cubanos, como Nicollas Guillén.

(...) O trabalho de Daniel Viglietti, no final da década de 60, juntou o folclore uruguaio às tendência políticas que o movimento da Nueva Cancion Chilena propagava por toda a América Latina. Entre os compositores que influenciaram o trabalho de Viglietti estão Victor Jara, Violeta Parra, Patricio Manns e Atahualpa Yupanqui. (...) Um anos após lançar o álbum Canto libre, em 1971, lançou no mercado o disco Canciones Chuecas, dedicado a figura de Chueco Maciel, ou a todos os chuecos de carne e osso, frágeis, imperfeitos humanos, mas que com o último de seus brios atacam a sociedade que os atacou primeiro, que os marginalizaram e os condenaram. Palavras do próprio Viglietti.

Abílio Manuel, no seu comentário, aponta para as estreitas relações entre o repertório de Viglietti e os compositores da Nova Canção Chilena, e termina

${ }^{16}$ GOMES, C. de S. "Quando um muro separa, uma ponte une" conexões transnacionais na canção engajada na América Latina (anos 1960/1970). Dissertação de mestrado defendida no Programa de Pós-graduação em História Social da FFLCH da USP em 2013. 
lembrando da figura lendária que inspirou o disco Canciones Chuecas, Chueco Maciel. Dessa vez, não se preocupa em dissimular sua opção por canções comprometidas ou, em outras palavras, por um repertório militante de esquerda.

\section{Os discos derivados do programa}

São também desta segunda fase, respectivamente de 1978 e de 1979, os discos lançados pelo selo Bandeirantes como subproduto do programa América do Sol I e II. O repertório selecionado por Abílio Manuel e editado pela Band para o volume I traz Violeta Parra, Mercedes Sosa, Quilapayun, Atahualpa Yupanqui, Rolando Alarcon, Isabel e Angel Parra, Las Cuatro Brujas, Victor Jara e Inti-illimani. Entretanto, a despeito de veicular um grupo de artistas engajado politicamente, com exceção de Las Cuatro Brujas, foram selecionadas canções predominantemente folclóricas ou românticas. Diferentemente de um programa radial, o disco significava um produto com maior perenidade, o que talvez explique a opção contemporizadora. O volume II, de 1979, segue a mesma tendência, reunindo canções folclóricas de diferentes regiões da América Latina, além de Silvio Rodrigues, cantando Pequeña serenata diurna, e Daniel Viglietti, com Desalambrar. O primeiro disco traz na capa a fotografia de um índio andino, trajado com roupas típicas e tocando um charango. O segundo apresenta a imagem de uma mulher, também com vestimentas andinas e traços indígenas, manuseando um tear. As duas ilustrações sugerem a identidade de uma América distante do progresso, da modernidade e orgulhosa de suas raízes.

Embora os discos não trouxessem exatamente a música de protesto, para os ouvintes do programa, potenciais consumidores dos Lps, e para todos aqueles que se identificavam com o repertório, escutar zampoñas, quenas, charangos, bombos e canções cantadas em espanhol, tinha em si um significado político bastante objetivo: a resistência contra as ditaduras da região e seu aliado, os Estados Unidos. Nas palavras de um dos músicos da banda Tarancon: “... trazer para o Brasil o 
folclore da Bolívia, significava unir os povos, quebrar fronteiras. Já que a pobreza era igual, a exploração era igual e as soluções eram iguais." 17

O programa ainda renderia mais dois discos, América do Sol Especial, editado pela Copacabana e Nueva Cancion de Chile, lançado pela Band ${ }^{18}$ também em 1978.

Em 1981, a rádio Bandeirantes mudava de direção e, segundo Abílio Manuel, rompia com esta linha mais alternativa, apostando numa grade de programas mais comerciais. América do Sol, depois de cinco anos no ar, ficaria fora do dial até 1984, quando a USP FM manifestaria seu interesse em veiculá-lo. Aí permaneceria hospedado até 1986, ano de mudança de reitor e, consequentemente, de seus assessores. Em meados da década de 1980, com o país no auge do processo de redemocratização, após a campanha pelas Diretas já e o fim do regime militar com a eleição de Tancredo Neves, América do Sol deixava definitivamente as ondas do rádio, com certeza da missão cumprida.

\section{Considerações finais}

No Brasil, a Nova Canção teve uma trajetória muito particular. As primeiras apresentações deste repertório ocorreram somente na década de 70, em plena ditadura militar, quando a censura tentava excluir do circuito musical canções brasileiras que, de alguma maneira, faziam a crítica ao cenário político nacional.

Nomes importantes como Milton Nascimento, Elis Regina e Chico Buarque trouxeram para os seus álbuns canções de Violeta Parra, Atahualpa Yupanqui ${ }^{19}$, fizeram parcerias com intérpretes do porte de Mercedes Sosa, produzindo discos e shows ${ }^{20}$, e até compuseram canções inspiradas na tradição

\footnotetext{
17 Depoimento concedido à autora por Sérgio Ferez (Turcão).

18 No Brasil, além dos selos alternativos que atendiam às demandas das bandas nacionais (Tarancon e Raíces de America) gravadoras como Odeon, RCA-Victor, e Copacabana também investiram no gênero e seus derivados.

${ }_{19}$ Em 1976, em seu disco "Falso Brilhante" a canção imortal de Violeta, Gracias a la vida e Los hermanos, de Atahualpa Yupanqui, dividiam as faixas do Lp com a já consolidada MPB.

${ }^{20}$ Milton Nascimento foi o músico brasileiro que mais se identificou com o movimento. O disco "Corazón Americano", lançado em 1985, é resultado de um show gravado ao vivo, realizado em parceria com Mercedes Sosa e Leon Gieco, em 1984
} 
musical dos países vizinhos ${ }^{21}$. Artistas menos inseridos no mainstream, como Abílio Manuel, os grupos Tarancón e Raíces de América22, estabeleceram vínculos ainda mais fortes com o repertório da Nova Canção, sendo responsáveis pela divulgação de inúmeros compositores, intérpretes e canções dos países vizinhos entre a juventude brasileira.

Desta safra mais alternativa, Abílio Manuel seja talvez o artista mais controvertido. Estudante da USP, numa época de grande efervescência política, participou e venceu festivais da canção no Brasil e no Chile, com canções românticas distantes do tom engajado que marcou a MPB do período. Na década de 1970, quando a ditadura havia conseguido impor o silêncio às vozes dissonantes, e poucos eram aqueles que ousavam burlar a censura, Abílio assumia uma posição política mais assertiva e fazia da música latino-americana um símbolo sonoro de resistência à ditadura militar.

Além de América Morena, o artista lançou mais dois Lps Becos E Saídas, em 1978, pela Som Livre, e Curso das Águas, em 1984, pela RCA. Becos e Saidas é entre seus discos o que talvez guarde relações mais próximas com América Morena, de 1976. As canções são quase todas de sua autoria, divindindo-se entre temáticas românticas; outras ligadas ao universo rural, como "Peão e viola" e "Colheita"; canções folclóricas, como a brasileira "Reis e folia" e a portuguesa "Milho verde"; e as que dialogam com o cancioneiro latino-americano, como "Pobre del cantor", da autoria do cubano Pablo Milanês, interpretada em espanhol por Abílio Manoel e "Los pueblos", composta em parceria com Halter Maia, cantada em espanhol e português. As sonoridades regionais e por vezes latino-americanas dominam os arranjos do disco.

Na década de 1980, com a redemocratização do Brasil e dos demais paises da região, esvaziaram-se as bandeiras de luta que nos aproximavam das nações vizinhas. No rumo dos acontecimentos, a música latino americana retornava às suas

\footnotetext{
${ }^{21}$ Chico Buarque grava, de sua autoria, em 1978, Cancion por la unidad latinoamericana.

22 O grupo Raíces de América foi criado em 1980, pelo empresário Enrique Bergen, a fim de aproveitar a recepção positiva da Nova Canção e seus "derivados" no mercado fonográfico. Formado por argentinos, chilenos e brasileiros, o grupo destacou-se pela qualidade de seus músicos e arranjos e pela concepção dos seus shows elaborados com sofisticação cênica. Uma das diferenças do Raíces em relação ao Tarancón esteve na incorporação, que fez o primeiro, dos instrumentos eletrônicos ao lado dos típicos instrumentos acústico da música latino-americana.
} 
fronteiras de origem, permanecendo na memória dos brasileiros como lembrança de um tempo em que fomos, talvez, mais latino-americanos.

\section{Bibliografia}

DENIS, Benoit. Literatura e engajamento, Bauru, SP. Edusp, 2002.

DICIONÁRIO Cravo Albin da Música popular Brasileira.

GARCIA, Tânia. Taracón: a invenção sonora de um Brasil latino-americano. ArtCultura, vol. 8, n.13, julho-dezembro de 2006.

GOMES, C. de S. "Quando um muro separa, uma ponte une" conexões transnacionais na canção engajada na América Latina (anos 1960/1970). Dissertação de mestrado defendida no Programa de Pós-graduação em História Social da FFLCH da USP em 2013.

NAPOLITANO, M. A produção do silêncio e da suspeita: a violência do regime militar contra a MPB nos anos 70. In Atas do III Congresso da IASPM realizado no Rio de Janeiro em 2004.

OLIVEIRA, F. Em um porão de São Paulo: o Lira Paulistana e a produção alternativa. SP. Annablume/Fapesp, 2002. 